Bogusław GÓRKA

(Gdańsk, UG)

\title{
OBRAZ BOGA W BIBLII
}

Mentalność chrześcijańską dominuje przeświadczenie, że człowiek jest obrazem Boga z racji stworzenia. Stwarzając człowieka, Bóg wyposażył go w takie atrybuty, które powoduja, że jest on kimś wyjątkowym pośród stworzeń, np. góruje nad światem zwierząt. Obrazowość Boga w człowieku wyraża się przede wszystkim w tym, że jest on osobą, istotą cielesno-duchową, racjonalną, wolną, duchową i społeczną. Taką samą doktrynę, która jest zakorzeniona również w twórczości wielu Ojców Kościoła, transmituje m.in. Katechizm Kościoła Katolickiego, który jeden z paragrafów (nr 355-384) poświęca człowiekowi stworzonemu na obraz Boga .

Ten bezdyskusyjny dzisiaj chrześcijański aksjomat odwołuje się bezpośrednio do motywów zamieszczonych w tzw. prehistorii biblijnej. Jednak problem polega na tym, że tak pojmowana obrazowość Boga w człowieku, jako obrazowość ontyczna, nie jest wcale przedmiotem zainteresowania Biblii. Przedmiotem zainteresowania autorów biblijnych jest coś zupełnie innego obrazowość egzystencjalna. W tym przyczynku postaram się ukazać, jaka rzeczywista doktryna o obrazie Boga wyłania się z kart Biblii.

\section{BIBLIJNY MODEL ADAMA}

W Księdze Rodzaju, w tzw. prehistorii biblijnej, znajdują się dwa opisy „stworzenia Adama”. Pierwszy, młodszy (1, 26-31), uczeni z reguły zaliczaja do tzw. tradycji kapłańskiej (P), drugi, starszy $(2,7-25)$ - do tradycji jahwistycznej $(\mathrm{J})$. W porządku narracji młodszy opis poprzedza starszy, ale został z nim z rozmysłem skorelowany. ,Redaktorzy Biblii pozostawili obydwa opisy, dość odległe od siebie czasem, językiem, duchem i horyzontem teologicznym, i zestawili je obok siebie po to, aby relatywizowały się w drugorzędnych detalach, a potwierdzały się w pierwszorzędnej wymowie ideowej”2 $\mathrm{Z}$ analizy

${ }^{1}$ Por. Katechizm Kościoła Katolickiego, Poznań 1994, 91-96. Np. pod nr. 357 (s. 91) czytamy: „Człowiek, ponieważ został stworzony na obraz Boży, posiada godność osoby: nie jest tylko czymś, ale kimś. Jest zdolny poznawać siebie, panować nad sobą, w sposób dobrowolny dawać siebie i tworzyć wspólnotę z innymi osobami".

${ }^{2}$ B. Górka, Biblia i cywilizacja Boga, Kraków 2004², 17. 
obydwóch narracji o „stworzeniu” wyłania się model istoty ludzkiej jako istoty integralnej, funkcjonującej w relacjach. Oto relacje wyłuskane stamtąd:

1. Do planety ziemi. Związek Adama z ziemią został wyartykułowany na pierwszym miejscu, a zasygnalizowany terminologicznie, gdzie słowo 'Adam (אדם) jest spokrewnione z terminem 'adamah (אדמה) - ziemia (Rdz 2,7)3. Ziemia niejako wchodzi w definicję Adama, który nie może egzystować poza zieloną planeta, bo nie jest kosmitą ani aniołem. Jest po prostu ziemianinem.

2. Do społeczności. W relacji do Boga występuje człowiek jako gatunek, a zarazem jako osobnik, który wraz z innymi osobnikami tworzy społeczność. Ta społeczność jest postrzegana przez pryzmat pary słów: zachar we-neqewah (זכר ונקבה) bara' 'otam, czyli: kobieta i mężczyznq stworzyt ich - albo precyzyjniej: w rodzaju męskim i żeńskim stworzyt ich (Rdz 1,27). Istotą społeczności jest zróżnicowanie na dwie płci, powiązane ze sobą i skierowane na siebie. Społeczności Boga w zamyśle Biblii nie tworzą singlowcy czy dwupłciowcy.

3. Do środowiska naturalnego. Adam jest pierwszym ekologiem, gdyż ma się troszczyć o ekosystem. Tę jego troskę o ekosystem Biblia wyraża za pomocą trzech słów: stużyć i strzec (שמר i עבד - 'awad i szamr: Rdz 2,15) oraz udoskonalać (כבש -kawasz: Rdz 1,28). Adam ma służyć ekosystemowi ,analogicznie do służby Bogu, ma strzec go - analogicznie do pieczy i troski pasterza nad trzodą owiec"6. Tutaj mamy skonstatowany postulat kultury jako udoskonalenia natury; środowisko naturalne zostało dane Adamowi, aby je rozwijał i ulepszał z poszanowaniem jego praw.

4. Do świata istot żywych. Biblijna „,narracja o stworzeniu” akcentuje dwie rzeczy: ontyczną przepaść między Adamem a pozostałymi istotami żyjącymi oraz jego przewagę nad nimi a zarazem ich uległość wobec niego ${ }^{7}$.

5. Do małżeństwa. W narracji biblijnej Adam w pewnym momencie staje się 'isz (איש) mąż przez odniesienie do 'iszah (אישה) ,mężyna” lub ,mężo-

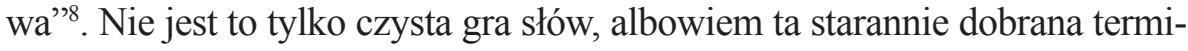

${ }^{3}$ Por. Rdz 2, 7: „Pan Bóg ulepił Adama z prochu ziemi i tchnął w jego nozdrza tchnienie życia”. Tłumaczenia bez odnośnika są mojego autorstwa.

${ }^{4}$ Por. Rdz 2, 15: „Pan Bóg zatem wziął Adama i umieścił go w ogrodzie Eden, aby mu służył i strzegł go".

${ }^{5}$ Por. Rdz 1, 28: „Abyście udoskonalali kraj”.

${ }^{6}$ Górka, Biblia i cywilizacja Boga, s. 20 - z powołaniem się w nocie nr 9 na: M. Filipiak, Biblia jako tekst religijny i kulturowy, Lublin 1993, 33-34.

${ }^{7}$ Por. Rdz 2, 19: „Ulepiwszy z ziemi wszelkie zwierzęta lądowe i ptaki powietrzne, Pan Bóg przyprowadził je do Adama, aby zobaczyć, jakie imię nada im. Wszystkich Adam obdarzył imieniem: 'istota żywa'. [...] ale dla człowieka nie znalazła się odpowiednia pomoc spośród zwierząt"; Rdz 1, 28: ,[...] abyście panowali nad wszystkimi istotami żywymi”.

${ }^{8}$ Por. Rdz 2, 21-23: „Wtedy to Pan sprawił, że Adam pogrążył się w głębokim śnie, i gdy spał, wyjął jedno z jego żeber, a miejsce to zapełnił ciałem. Po czym Pan Bóg z żebra, które wyjął z Adama, zbudował niewiastę. A gdy ją przyprowadził do Adama, Adam powiedział: ta dopiero jest kością z moich kości i ciałem z mego ciała. Ta będzie się zwała mężową, bo ta z męża została wzięta". 
nologia sygnalizuje pokrewieństwo męża i żony w wymiarze ontologicznym. W małżeństwie do definicji męża wchodzi żona („mężyna”) i na odwrót tak dalece, że w zjednoczeniu męża i żony realizuje się pełnia człowieczeństwa.

6. Do rodziny. Małżeństwo biblijne ukierunkowane jest na wydanie owoców w mnogości: owocujcie i pomnażajcie się (Rdz 1,28: פרו ורבו - - $\left.^{e} r u u^{e} w u\right)$.

7. Do Boga. Biblia relację do Boga artykułuje w dwóch słowach: celem $i$ demut (צלם ודמות-obraz i postać - Rdz 1,26n.). Tę relację poddamy teraz gruntowniejszej analizie.

\section{ADAM JAKO OBRAZ (I POSTAĆ) BOGA (Rdz 1, 26-28)}

Odniesienie do Boga jest relacją fundamentalną. Chociaż odniesienie do Boga „rodzica” zna starożytny Orient, to jednak religia izraelska modyfikuje tę doktrynę o nowy element: Bóg człowieka tworzy, a nie rodzi. Orient zna również ideę obrazu i postaci. Obraz wyraża ideę reprezentacji, a postać ideę podobieństwa. Te idee uzyskują w tradycji biblijnej nową jakość między innymi przez sposób odniesienia ich do Boga. Skoncentrujemy się teraz na wyjściowym tekście biblijnym, w którym występuje idea obrazu. Najpierw przytoczę wersję hebrajska, a potem tłumaczenie Septuaginty (LXX) oraz przekład na język polski.

\section{Biblia hebrajska':}

\section{וייומר אלהים: נעשה אדם בצלמנו כדמותנו... וייברא אלהים את האדם בצלמו, בצלם אלהים ברא אותו, בכר ונקבה ברא אותם}

Wa-jomer 'Elohim: na'aseh 'adam be-calmenu ki-d'mutenu...

Wa-jiwra' 'Elohim et ha-'adam be-calmo, be-celem 'Elohim bara' 'oto, zachar u-neqewah bara' 'otam.

\section{$\underline{\text { Septuaginta }}^{10}$ :}

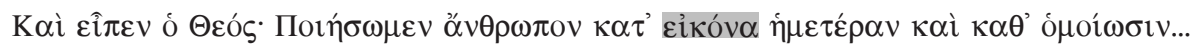

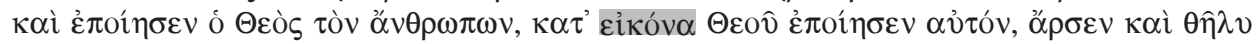

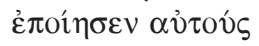

I powiedział Bóg: uczyńmy Adama na nasz obraz i naszą postać...

Stworzył więc Bóg tego Adama na swój obraz, na obraz Boga stworzył go; mężczyzną i kobietą stworzył ich.

Septuaginta pomija w thumaczeniu jeden z trzech hebrajskich słów „obraz” (celem), jednak przez to nie demoluje sensu oryginału.

\footnotetext{
${ }^{9}$ Por. Biblia Hebraica Stuttgartensia, ed. R. Kittel i inni, Stuttgart 1967/1977.

${ }^{10}$ Por. Septuaginta, ed. A. Ralhlfs, vol. 1, Stuttgart 1979, 2.
} 
1. Obraz Boga a model progresywnej religijności. Problem powstaje już przy stylistycznej próbie odczytania „,dekretu stworzenia”; gdzie postawić znak przestankowy? Po: „uczyńmy, Adama na nasz obraz...”, czy po: „uczyńmy Adama, na nasz obraz...”. W pierwszym wypadku „dekret” dotyczyłby stworzenia Adama z dwoma osobliwymi atrybutami, w drugim - obdarzenia istniejącego już Adama atrybutami: obrazu i postaci Boga.

Częściowa odpowiedź na ten problem zawiera się w realizacji „dekretu stworzenia". Wprawdzie Bóg postanowił stworzyć Adama na Swój obraz i Swoją postać, to jednak nieopodal mowa jest o tym, że stworzył go tylko na Swój obraz, czyli że zrealizował jedynie pierwszą część Swojej zapowiedzi. Zatem kiedy zostanie zrealizowana druga część „dekretu”, czyli, kiedy Adam uzyska status ,postaci Boga”?

W postępie narracji biblijnej nie ma o tym mowy wprost i trzeba się tego domyślać z lektury drugiego opisu. Wiele na to wskazuje, że realizacja drugiej części „dekretu” nastąpiła wówczas, gdy Adam jako „proch z ziemi” został ożywiony przez Boga i, jako taki, został wprowadzony do raju ${ }^{11}$. Wniosek tego rodzaju jest uprawniony, gdy należycie postrzega się specyfikę tradycji biblijnej, w której zredagowano tzw. prehistorię biblijną. Powstała ona najwcześniej wtedy, gdy Izrael przekształcił się w królestwo. Wówczas opracowano teologię wspartą na progresie wydarzeń: wyjście z Egiptu, nadanie Tory, przejście po pustyni, wejście i podbój Ziemi Obiecanej oraz stworzenie królestwa (później do tego szablonu dojdą: grzech, upadek królestwa i deportacje oraz nadzieja odrodzenia, powrót i odbudowa). W wyniku tego zabiegu powstał model progresywnej wiary.

Ten model w zależności od potrzeby rzutuje się w przeszłość, albo w przyszłość, czy też weryfikuje się nim teraźniejszość. Za tą operacją stoi ugruntowana intuicja teologalna, że skoro Bóg dokonał interwencji w dzieje w określonym szablonie, to ten szablon powielił na innym poziomie $\mathrm{w}$ prehistorii i powieli go na głębszym poziomie w eschatonie oraz według tego samego modelu realizuje aktualnie swoją zbawczą wolę.

2. Sens wyrażenia obraz Boga. Według progresywnego modelu konstruuje się opowieść „,o obrazie i postaci Boga”. Biblia nie wykazuje zainteresowania zagadnieniem, czy i w jakim zakresie istota ludzka z racji stworzenia (status ontyczny) jest nośnikiem „obrazu i postaci Boga”. Dla Biblii żywotna kwestią jest pytanie o egzystencjalny stan istoty ludzkiej jako „obrazu i postaci Boga", pytanie o to, kiedy istota ludzka w swojej egzystencjalnej kondycji osiaga ten stan. Teolodzy biblijni nie interesują się więc kwestią, jaką istotę ludzką stwarza Bóg, gdy ją powołuje z nicości do bytu, ale faktem, kiedy to

${ }^{11}$ W tym wypadku ,proch z ziemi” w Rdz 2, 7 byłby metaforą Adama przed ożywieniem, a nie ekwiwalentem materialności cielesnej. W epoce apologetów dwa momenty stworzenia wyróżniał Tertulian, ukształtowanie z materii i tchnienie życia, por. De resurrectione carnis 5, 8-9, CCL 2, 927. 
Bóg sprawia, że istniejąca istota ludzka staje się najpierw „obrazem Boga”, czyli Człowiekiem przez duże C, Anthroposem. Zatem proceder zredukowania sensu biblijnego obrazu Boga (czyli sensu egzystencjalnego) do sensu ontycznego „obrazu Boga” jest jednym z większych nieporozumień w teologii chrześcijańskiej. W efekcie atrybut „postaci Boga” staje się problematyczny albo zbędny i dlatego w trakcie interpretacji bezzasadnie pomija się go czy traktuje jako synonim atrybutu „obrazu Boga”. Tę tradycję omisji atrybutu „postaci Boga” czy raczej utożsamienia go z atrybutem „obrazu Boga” kontynuują także autorzy Katechizmu Kościoła Katolickiego ${ }^{12}$.

\section{OBRAZ BOGA JAKO ANTHROPOS W J 1, 6}

Janowy Prolog jest specyficznym typem literatury biblijnej. Od strony merytorycznej ma za zadanie wprowadzić czytelnika w świat Janowych sensów. Poczesne miejsce w Prologu zajmuje postać Jana Chrzciciela, gdzie pojawia się aż dwukrotnie. Pierwszy raz zjawia się Jan Chrzciciel w wierszu 1, 6. Ma to miejsce po pierwszej sekwencji o Logosie $(1,1-5)$, którą zamyka motyw,

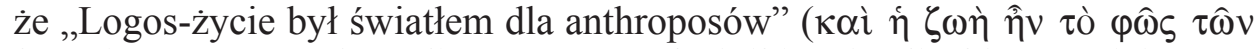

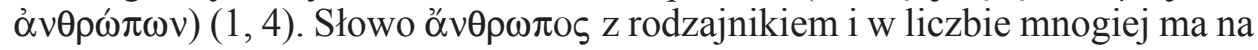
uwadze określoną grupę inicjowanych, dla których Logos, jako światło, jest przeznaczony. Do tego motywu powróci Jan w wierszu 1, 9. W tych wersach, spotykamy się oczywiście z kategorią teologiczną anthroposa, a nie z kategoria antropologiczną ${ }^{13}$. W tym samym znaczeniu - teologicznym, pojawia się ő $v \theta \rho \omega \pi \circ \varsigma \mathrm{w}$ interesującym nas miejscu w odniesieniu do Jana Chrzci-

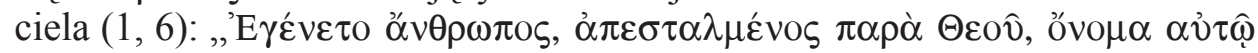
'I $\omega \alpha \dot{\nu} \nu \varepsilon \varsigma^{\prime \prime}$ '14.

1. Kwestia translacji tekstu. Wulgata, będąc praprzekładem, tłumacząc w. 1, 6 jako: „fuit homo missus a Deo, cui nomen erat Iohannes” ${ }^{15}$, sprokuro-

${ }^{12}$ W całym paragrafie traktującym o „obrazie Boga” (nr 355-361), autorzy Katechizmu nie poświęcają żadnej uwagi ,idei postaci (czy podobieństwa) Boga”. Idea „,podobieństwa Boga” pojawia się raz akcydentalnie w cytacie pochodzącym ze Sermones Piotra Chryzologa (Sermones 117, 1-2, PL 52, 520B lub CCL 24A, 709) - oczywiście jako synonim „obrazu Boga”, por. Katechizm Kościoła Katolickiego, s. 92.

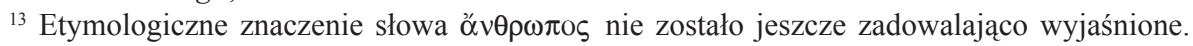
Wiadomo na pewno, że pochodzi ono ze źródła mykeńskiego i jest w użyciu od czasów Homera, por. P. Chantraine, Dictionnaire étymologique de la Langue Grecque, t. 1, Paris 1968, 90-91; R. Beekes - L. van Beek, Etymological Dictionary of Greek, Leiden - Boston 2010, 106.

${ }^{14}$ Tekst Prologu przytaczam za: The Greek New Testament, red. B. i K. Aland - J. Karavidopoulos - C.M. Martini - B.M. Metzger, Stuttgart 1994, 313.

${ }^{15}$ Wulgatę cytuję za wydaniem krytycznym: Biblia Sacra iuxta Vulgata versionem, red. B. Fischer - J. Gribomont - H.F.D. Sparks - W. Thiele - R. Weber, Stuttgart 1975², 1658-1659. Interpunkcję w tekst Janowego Prologu wprowadzam za: Nova Vulgata, Roma 1979. Korzystam z wyda- 
wała całą serię nieadekwatnych translacji w chrześcijaństwie Zachodu. Przywołajmy celem ilustracji tego zjawiska polskie przekłady; trzy katolickie, jeden protestancki i jeden ekumeniczny.

- Biblia Tysiąclecia: „Pojawił się człowiek posłany przez Boga - Jan mu było na imię"16.

- Przekład egzegetyczny: „Wystąpił człowiek posłany przez Boga - na imię mu było Jan"17.

- Przekład interlinearny: „(Był) człowiek, wysłany od Boga, na imię mu Jan”"18.

- Biblia Warszawska: „Wystapił człowiek, posłany od Boga, który nazywał się Jan"19.

- Przekład ekumeniczny: „Był człowiek o imieniu Jan, posłany przez Boga”20.

Powyższe tłumaczenia zostały ,zniewolone Wulgatą” w przekładzie cza-

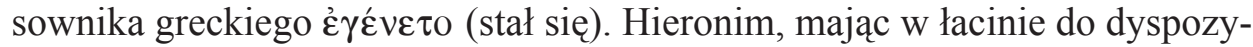
cji precyzyjne odpowiedniki dla greckich słów, w tłumaczeniu Prologu stosuje je niekonsekwentnie. Zna i respektuje dystynkcję między greckimi czasownikami „być” (દîvol) i stać się ( $\gamma^{\prime}(\gamma \nu o \mu \alpha \imath)$. Pierwszy tłumaczy przez łacińskie esse, drugi przez fio. Tak dzieje się do wiersza 1, 5. Nagle przy thumaczeniu wiersza 1, 6 Hieronim porzuca konsekwencję i grecki czasownik „stał się"

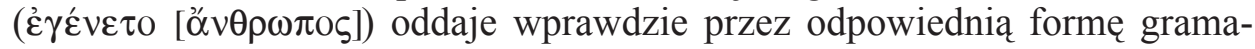
tyczną „fuit [homo]” - ale łacińskiego czasownika „być” (esse), a nie, jak powinno być, przez stosowną formę od łacińskiego czasownika „stać się” (fio).

Hieronim w thumaczeniu, owszem, zachowuje właściwe i adekwatne formy gramatyczne. W pierwszej części zdania greckie aoristum oddaje przez łacińskie perfectum, natomiast $\mathrm{w}$ drugiej jego części wprowadza orzeczenie w imperfectum, co jest zwyczajem przyjętym w łacinie odnośnie do opisu. Niewybaczalny błąd Hieronima polega na wyborze nieadekwatnego ekwiwa-

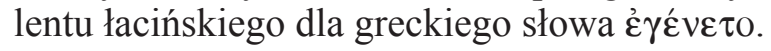

nia umieszczonego w: Novum Testamentum Graece et Latine, ed. K. Aland - M. Black - C.M. Martini - B.M. Metzger - A. Wikgren, Stuttgart 1979²6, 247-248.

${ }^{16}$ Pismo Święte Starego i Nowego Testamentu, Poznań - Warszawa 1980³, 1216.

${ }^{17}$ Ewangelia wedlug św. Jana. Wstęp, przekład z oryginału, komentarz L. Stachowiak, Poznań - Warszawa 1975, 104-124.

${ }^{18}$ R. Popowski - M. Wojciechowski, Grecko-polski Nowy Testament. Wydanie interlinearne z kodami gramatycznymi, Warszawa 1994, 391.

${ }^{19}$ Biblia to jest Pismo św. Starego i Nowego Testamentu, Warszawa 1975. Ewangelie zostały przetłumaczone jako pierwsze w 1964 roku.

${ }^{20}$ Pismo święte Nowego Testamentu i Psalmy. Przekład ekumeniczny z języków oryginalnych, Warszawa 2000, 203. Wprawdzie jest to dzieło ekumeniczne, niemniej jednak przekład Ewangelii Jana należy traktować jako tłumaczenie protestanckie, albowiem wyszło ono spod ręki luteranina, Manfreda Uglorza. W tym punkcie Prologu tłumacz dokonał także nieuprawnionego przekształcenia składniowego. 
2. Stat się anthropos - interpretacja inicjacyjna. Hermeneutom jakoś umyka oryginalność tej frazy już na poziomie jej struktury. Rozpoczyna ją czasownik, który staje się motywem wiodącym w wierszu. Przywodzi on na myśl proces rozwoju istoty ludzkiej. Na pewnym szczeblu tego procesu istota ludzka osiaga status anthroposa. Anthropos to efekt ewolucji istoty ludzkiej, której autorem jest oczywiście Bóg. Ów anthropos występuje tu bez rodzajnika określonego, a ta okoliczność sygnalizuje, że autor Ewangelii ma na uwadze jeden ,egzemplarz ze zbioru” anthroposów.

$\mathrm{Na}$ miejscu jest teraz pytanie, kiedy istota ludzka reprezentuje w swojej egzystencji status anthroposa. W sukurs przychodzi nam późniejsza teologia judaizmu, w której istota ludzka uzyskuje status Człowieka w momencie, gdy przyjmuje na siebie jarzmo Tory i przykazań. Żyd teoretycznie wchodzi w ten stan z natury, a praktycznie najpierw poprzez obrzęd $b^{e}$ rit milah (obrzezanie) a potem bar micwah (młodzieńcze wyznanie wiary), natomiast poganin wchodził w status obrazu Boga poprzez akt konwersji na judaizm.

Pozostaje nam odpowiedź na drugie pytanie, jaką konkretną zmianę egzystencjalną w kondycji ludzkiej powodował fakt stania się anthroposem? Pośrednio na nie odpowiada św. Paweł: „My z natury jesteśmy Żydami, a nie grzesznikami z pogan" $(\mathrm{Ga} 2,15)$. Pawłowi chodzi tu o wolność od grzechów personalnych. Tę wolność uzyskiwał Żyd od Boga w oparciu o pedagogię Tory i Proroków. O takiej personie informuje nas zapewne J 1, 6. W strukturze tej wypowiedzi Jan Ewangelista na drugim miejscu uwypukla fakt, że każda istota ludzka, która uzyskuje status anthroposa (obraz Boga, istota wolna od grzechów personalnych), może być, a w tym wypadku jest, posłana przez Boga. Słowo Bóg bez rodzajnika określonego sygnalizuje, że chodzi o Boga jako Boga, naturę Boga.

Nie jest prawdą, że w optyce biblijnej każda istota ludzka jest posyłana przez Boga. Trzeba na tę okoliczność odróżnić posłanie pozytywne od posłania negatywnego. Od Boga z misją pozytywną może wyjść dopiero anthro$p_{o s}{ }^{21}$, natomiast z misją negatywną - każda istota ludzka. Istota ludzka przybywa z misją negatywną np. wtedy, kiedy staje się bankrutem moralnym, ma tego świadomość i ostrzega innych przed konsekwencjami swoich grzechów.

W mentalności chrześcijan nie ma miejsca dla tej nowotestamentowej oczywistości odnośnie do pozytywnego i negatywnego posłania. Wyrazisty przykład nieporozumienia na tym odcinku znajduje się w jednym $\mathrm{z}$ dokumentów jezuickich. Tuż po Soborze Watykańskim II, w obliczu kryzysu, który najbardziej dotknał ten zakon, jezuici dwukrotnie zwołali Kongregację Generalną (XXXI i XXXII). Ożywione debaty podsumowywano w dokumentach

${ }^{21}$ Anthropos nie był jeszcze wolny od grzeszności naturalnej. Zatem zdanie, że „grzesznik, ale naturalny, jest posłany przez Boga" - jest jak najbardziej uprawomocnione nowotestamentalnie. Więcej informacji na temat idei grzeszności personalnej i naturalnej znajdzie uważny czytelnik w I Liście św. Jana. 
pokongregacyjnych. Dokument Kongregacji XXXII rozpoczyna znamienny dialog retoryczny: „Co to znaczy być jezuitą? Być jezuitą - to wiedzieć, że wprawdzie jest się grzesznikiem, ale posłanym przez Boga, jak niegdyś Ignacy (Loyola - B.G.), na towarzysza Jezusa Chrystusa"22. Starsi członkowie zakonu jezuitów, nieprzyzwyczajeni do tego rodzaju szczerości, oburzali się wówczas na ten zapis, bynajmniej nie z tego powodu, że kwestionowali prawdziwość jego sensu. Kwestionowali jedynie zasadność tego rodzaju publicznej wiwisekcji, utyskując: „Dominikanie też są grzesznikami, ale nie piszą o tym otwarcie w swoich oficjalnych dokumentach...”. W gruncie rzeczy ta udokumentowana samoocena jest teologalną bzdura, która poniekąd jako dogmat zagnieździła się w umysłowości chrześcijan.

Tą konkretną istota, posłaną w Janowym Prologu, jest anthropos określony imieniem $\mathrm{Jan}^{23}$ : oczywiście mowa tu o Janie Chrzcicielu. On otrzymał od Boga misję jedyną w swoim rodzaju: świadczenia o Logosie jako świetle, ale ten temat przekracza ramy tego przyczynku.

\section{OBRAZ JEGO SYNA W Rz 8, 29.}

Śledząc w Nowym Testamencie motyw obrazu Boga, natrafiamy pod koniec ósmego rozdziału Listu do Rzymian na oryginalną kompozycję:

Rz 8, 28: „Wiemy zaś, że z miłującymi Boga wszystko współpracuje ku dobru, z tymi, którzy są powołani według postanowienia [Jego]".

Rz 8, 29: „Bo których wcześniej poznał, tych przeznaczył, aby zostali współuformowani z obrazem Jego Syna aby On był pierworodnym wśród wielu braci".

Rz 8, 30: „Których przeznaczył, tych powołał, których powołał, tych usprawiedliwił, których usprawiedliwił, tych uwielbił"24.

Ta kompozycja stanowi wprawdzie merytoryczną całość, niemniej jednak dla potrzeb naszej debaty skupimy się na jej środkowym zdaniu $(8,29)$.

${ }^{22}$ Dekrety Kongregacji Generalnej XXXII, Rzym 1975, 7. Tłumaczenie polskie, z którego korzystam, opatrzone jest jedynie datą wydania - 1976. Skądinąd mi wiadomo, że dokumenty te przetłumaczono i wydano w Krakowie z inicjatywy Prowincjalatu Prowincji Polski Południowej Towarzystwa Jezusowego.

${ }^{23}$ Jan Ewangelista w 1, 6 ma na myśli bezpośrednią misję od Boga, a nie pośrednią - np. za pośrednictwem jakiejś instytucji.

${ }^{24}$ Rom 8, 28-30 (Novum Testamentum Graece, ed. B.K. Aland - J. Karavidopoulos, dz. cyt.):

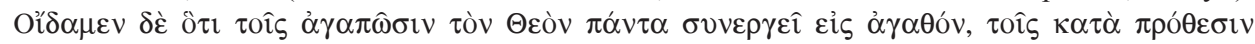

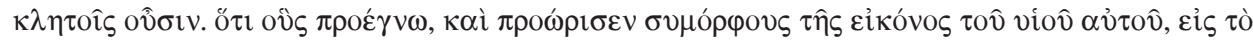

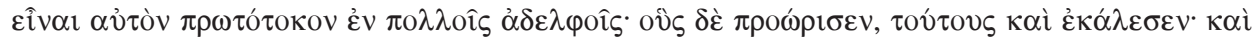

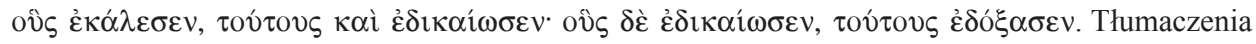
są mojego autorstwa. 
1. Oryginalność frazy? Paweł w tej perykopie przedstawia dynamikę i etapowość wczesnochrześcijańskiej inicjacji. Pojawiające się określenia nawiązują do szczebli inicjacyjnych. „Miłujący Boga” są ekwiwalentem powołanych $(8,28)$. Z powołanymi współpracuje wszystko ku dobru, które w wierszu 8, 30 zostaje dookreślone jako egzystencjalne usprawiedliwienie w wierze Jezusa Boga $^{25}$. To usprawiedliwienie zostaje zdefiniowane w wierszu 8, 29 jako „współuformowanie z obrazem Jego Syna”.

Wyrażenie „współuformowanie z obrazem Jego Syna” jest poniekąd dziewicze w NT, ale podobna idea pojawia się w 2 Kor 3,18, gdzie zwrot „obraz

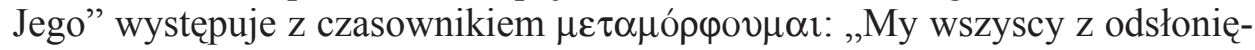
tą twarza, odzwierciedlając chwałę Pana, za sprawą Ducha Pana, jesteśmy przeformowywani na obraz Jego od chwały do chwały". Natomiast w Flp 3,

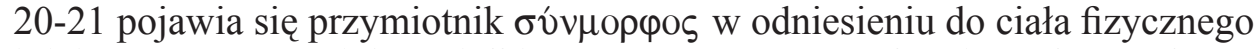
inicjowanego oraz ciała uwielbionego Jezusa: „Nasze bowiem obywatelstwo jest w niebiosach, z których wyczekujemy Zbawiciela, Pana Jezusa Mesjasza, Który przekształci postać naszego ciała uniżenia na współuformowaną z ciałem Jego chwały."

2. Interpretacja inicjacyjna $\mathbf{R z} \mathbf{8}, \mathbf{2 9}$. W dotychczasowej hermeneutyce Rz 8, 29 pod słowem obraz (عikóv) identyfikuje się Jezusa Chrystusa jako Syna Boga. Tymczasem rzecz ma się bardziej skomplikowanie już przy uważnym wpatrzeniu się w samą strukturę wyrażenia. Występują w nim dwa różne składniki: „obraz” i „Jego Syn”. Ewidentnie „Jego Syn” nie jest tożsamy z „obrazem”! Zwrot „Jego Syn” występuje w odniesieniu do „obrazu”, który jest niewątpliwie metafora. Ale metaforą kogo? Kto zatem jest owym „obrazem”? Bezdyskusyjnie „obrazem” jest Jezus jako Człowiek umierający na krzyżu. Trzeba pamiętać o tym, że Jezus jako Człowiek jest Synem Boga i jako Bóg jest Synem Boga. Na krzyżu umiera Jezus Syn jako Człowiek, a nie jako Bóg. Tę podwójną filiologię (filius + logos) wypowiada tutaj Paweł przy pomocy tego jakże lapidarnego wyrażenia: „obraz Jego Syna”.

W tym wyrażeniu Jezus jako „obraz” nie występuje w relacji do Boga jako Boga, czy do Boga jako Ojca, lecz do Siebie jako Syna Boga. Jezus jako Człowiek wiszący na krzyżu jest obrazem Siebie jako transcendentnego Syna Boga! Inicjowani w akcie usprawiedliwienia są współuformowani $\mathrm{z}$,obrazem” Jego Syna, a nie z „Jego Synem”! Innymi słowy inicjowany w akcie usprawiedliwienia wchodzi w morfe Jezusa Chrystusa jako Człowieka umierającego na krzyżu. I to właśnie uwypukla Paweł, przywołując po mistrzowsku doktrynę o podwójnej filiologii (podwójne synostwo) ${ }^{26}$.

${ }^{25}$ Por. B. Górka, Hermeneutyka inicjacji wczesnochrześcijańskiej, Kraków 2007, 38-39.

${ }^{26}$ Zwrot „obraz Jego Syna” przywołuje także relację wewnątrztrynitarną Jezusa Syna Boga do Boga jako Ojca. 
Współuformowanie inicjowanego z „obrazem Jego Syna” jest ścisłym odpowiednikiem innych nowotestamentowych wyrażeń, wypowiadających ideę współumierania $\mathrm{z}$ Jezusem. To jest akt usprawiedliwienia w sensie ścisłym, który jest skutkiem zbawienia egzystencjalnego przez Jezusa Syna Boga $\mathrm{z}$ fundamentalnego grzechu, naturalnego. Potem w momencie wskrzeszenia z martwych Jezus wchodzi w status "postaci Siebie (postać Jego Syna), ale tym doniosłym zagadnieniem nie zajmujemy się w tym przyczynku.

\section{POTRÓJNY OBRAZ BOGA W JEZUSIE}

W Janowym Prologu Jezus Syn Boga jako Człowiek - w odróżnieniu od Jana Chrzciciela, który stat się anthroposem - posiada status obrazu Boga $\mathrm{z}$ natury, bowiem z Boga się narodził $(\mathrm{J} 1,13)^{27}$.

W status obrazu Siebie jako Boga wszedł Jezus w momencie śmierci na krzyżu, kiedy w pełni objawiło się Jego podwójne synostwo. Ponieważ w proces zbawienia zaangażowane są trzy Osoby Boga, zatem Jezus jako Człowiek wszedł również w status obrazu Ducha Świętego. Wprawdzie w Nowym Testamencie nie mówi się wprost o obrazowaniu Ducha Świętego w Jezusie, to można bezpiecznie założyć, że dokonało się to po Jego zmartwychwstaniu.

Jezus jako Człowiek, będąc w procesie zbawienia medium Boga w trzech Osobach, jest w procesie inicjacji wzorem i przewodnikiem dla inicjowanego. Inicjowany przechodząc wtajemniczenie w Bóstwie Ojca i Syna, i Ducha Swiętego (por. Mt 28,19), ma uczestnictwo w potrójnym obrazowaniu Boga w Jezusie jako Człowieku (jak też i w potrójnym Jego upostaciowaniu). To obrazowanie jest fenomenem dynamicznym i procesualnym.

Obrazowanie Boga w inicjowanym, o którym raportuje Biblia, nie ma ani charakteru ontycznego ani moralistycznego, ale egzystencjalny i inicjacyjny. Usiłowanie ,załatwienia” tajemnicy obrazowania Trójcy Świętej w istocie ludzkiej na gruncie sakramentalizmu czy moralizmu, prowadzi do tego, że chociaż „wszystko gra” na poziomie esencji czy deklaracji, to jednak konkretna egzystencja ludzka pozostaje zniewolona podwójną grzesznością. Bo egzystencja ludzka może być regenerowana zbawczo jedynie w progresie inicjacyjnym.

Wielorakie świadectwo na oddziaływanie tego progresywnego szablonu $\mathrm{i}$ jego rangi w teologicznych dociekaniach na przełomie II/III wieku chrześcijaństwa, dostarcza twórczość Klemensa Aleksandryjskiego, ojca teologii biblijnej na podłożu filozofii greckiej. W jednym z dzieł, traktując o celu działania Jezusa jako Logosu w stosunku do inicjowanego, Klemens stwierdza, że staje się on „doskonały na obraz Jezusa jako Didaskalosa (Nauczyciela) - Boga przebywającego w ciele" ${ }^{\prime 28}$. Didaskalos jest w koncepcji Klemensa Lo-

\footnotetext{
${ }^{27}$ Paweł „obrazem Boga” nazywa także Jezusa jako Mesjasza w 2Kor 4, 4.

${ }^{28}$ Por. Clemens Alexandrinus, Stromata VII 101, 4, ed. O. Stählin, GCS 17, 71.
} 
gosem nauczajacym. Przedtem Logos najpierw zachęca, potem wychowuje ${ }^{29}$. Stąd też tytuły jego dzieł: Protrepticus i Paedagogus - warunkowane bez wątpienia programem inicjacji wczesnochrześcijańskiej.

Przytoczę na koniec jeszcze jeden przykład z Klemensa Aleksandryjskiego, z Wypisów z Theodota:

„[Człowiek] choiczny (ziemski) jest na obraz, [człowiek] psychiczny na podobieństwo Boga, zaś [człowiek] pneumatyczny - jest taki jak On sam”"»0.

Tym progresywnym modelem posługiwali się często gnostycy chrześcijańscy. Wprawdzie podkładali pod niego własną treść, niemniej jednak formę szablonu zapewne zaczerpnęli z wczesnochrześcijańskiej procedury inicjacyjnej.

$* * *$

Autorzy prehistorii biblijnej, konstruując dyskurs o obrazie Boga, chociaż nie mieli pojęcia o tym, jakiego rodzaju objawienie zaistnieje w eschatonie, to jednak wyrazili go w egzystencjalnym i progresywnym szablonie, który jest obowiązujący w eschatonie. Punktem wyjścia do nowotestamentowych dociekań na temat anthroposa-obrazu Boga jest starotestamentowy motyw obrazu $B o g a$ wyartykułowany w ewolucyjnym szablonie. Ten progresywny model obrazu Boga aktualizuje Jan Ewangelista w odniesieniu do osoby i misji Jana Chrzciciela, który w pewnym momencie stał się anthroposem. Natomiast Paweł adaptuje motyw obrazu do Jezusa w przełomowym momencie zbawczego procesu. Szczególnie ta druga adaptacja stanowi punkt wyjścia dla doktryny o potrójnym obrazowaniu Boga - tak w Jezusie, jak i w inicjowanym.

\section{THE IMAGE OF THE GOD IN BIBLE}

\section{(Summary)}

The standard interpretation of the biblical idea of the image of the God in Genesis (Gen 1:26 ff.), so called ontic interpretation, which sees in Him a religious basis for the metaphysical dogma of the creation of a man as a spiritualcorporeal being, is detached from its biblical meaning. For the biblical authors, the primary issue is not the question what kind of the human being was called by

${ }^{29}$ Por. Clemens Alexandrinus, Paedagogus I 3, 3, ed. O. Stählin, GCS 12, 91: „Logos najpierw

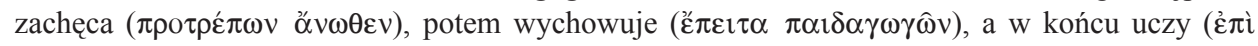
$\pi \hat{\alpha} \sigma \imath v \dot{\varepsilon} \kappa \delta \imath \delta \alpha ́ \sigma \kappa \omega v)$.

${ }^{30}$ Clemens Alexandrinus, Excerpta ex Theodoto 54, 2, GCS 17, 125 lub SCh 23, 170: „ó $\mu \dot{\varepsilon} v$

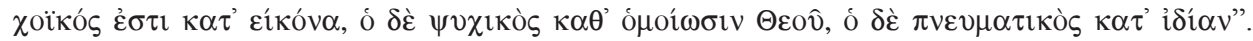
Ireneusz do obrazu Boga odnosił zbawczą regenerację ciała, do podobieństwa - regenerację duszy, por. Irenaeus, Adversus haereses V 6, 1, ed. A. Rousseau - L. Doutreleau - C. Mercier, SCh 153, 72-80, Paris 1969, 72-80. 
the God from nothingness into being, but that when the human being receives the status of the image and character of the God in the existential dimension.

John the Baptist reached the status of the image of God at the time when he became the Anthropos (John 1:6). In turn, Paul, by the moving of the idea of the image of Jesus as a man at the turning point of the process of salvation (Romans 8:29), created the foundation for the study of triple-imaging of the God as in Jesus, as well as in initiated. 